\title{
COPPER AND ALUMINUM IN CULTURAL HERITAGE: THE ANALYSIS OF DAMAGE THRESHOLD OF MATERIAL IN INTERACTION WITH RUBY LASER
}

\author{
B. Katavic ${ }^{1,}$, S. Ristić ${ }^{1}$, Z. Nikolićl ${ }^{1}$, S. Polić Radovanović ${ }^{2}$, \\ M. Vilotijević ${ }^{1}$, M. Puharić ${ }^{1}$ \\ ${ }^{1}$ Institute Gosa, Belgrade, Serbia \\ ${ }^{2}$ Central institute for conservation, Belgrade, Serbia
}

\begin{abstract}
Copper and aluminum are materials that have technological, functional and expressive value in the contemporary art and architecture. Therefore, studying the possibilities of protection of these materials by using non-destructive method is of great importance when it comes to cultural heritage. The paper presents the results of interactions of laser light with wavelength $\lambda=694.3 \mathrm{~nm}$ (Ruby laser, Q-switch mode) and metal samples, covered with a deposit. The goal of investigation was to determine the maximum energy density of the laser beam which can be used to remove deposit and does not interact with the basic material at the same time. The effects of laser interaction are investigated by SEM and EDX.
\end{abstract}

Keywords: laser, interaction, cultural heritage.

\section{INTRODUCTION}

Since the earliest written records the metals have been widely applied in architecture and construction items, which now represent artistic or archaeological artifacts.

Protection of cultural heritage is a complex, interdisciplinary activity, which is based on the application of new technologies, methods and materials. Nondestructive methods are dominant in diagnosing the state and protection of the cultural heritage objects. Laser method opens wide possibilities for research in the field of art and archaeological objects.

This paper presents the results of experimental investigations of the ruby laser light application in diagnosing and cleaning of objects made of copper and aluminum. The energy density of laser light with $\lambda=694.3 \mathrm{~nm}$, which can be safely used to clean the surface sediment on copper and aluminum samples is determined.

During different historical periods copper has been widely applied in architecture and construction items, which today represent artistic and archaeological objects of cultural heritage (copper was known 8000 years BC). Aluminum, however, was recognised as structural material in many buildings and statues at the end of the nineteenth century. Twenty-first century brought new possibilities of copper and aluminum application in the art, emphasizing the expressive value of these metals (Fig. 1 and 2). The use of copper and aluminum in the art, points out at the necessity of metal artifacts protection and conservation. Laser methods open wide possibilities of research in the field of diagnosis and metal cleaning [1-10].

\section{TESTING METHODS}

Excimer lasers, with wavelengths in the ultraviolet spectrum, Nd-YAG with multiple wavelengths, and $\mathrm{CO}_{2}$ lasers have been very useful in protection of cultural heritage. The data on the effects of laser light and various materials interaction can be found in extensive literature [7-19].

The effects of excimer and Nd-YAG lasers interaction are the most widely investigated. Fewer projects dealt with testing the effects of interaction of ruby laser light and objects of cultural heritage. The largest part of the metal has a low absorption coefficient of visible spectrum, while the reflection coefficient varies from 30 to $95 \%$, depending on sediments and the quality of surface treatment $[18,19]$.

The coefficient of visible light reflection from metal surfaces is very high, but it is possible to create the unwanted conditions of interaction of light with the surface during the application of diagnostic methods based on laser techniques (interferometry, holography, 3D scanning and so on. $[17,18])$. It can cause various damage. 


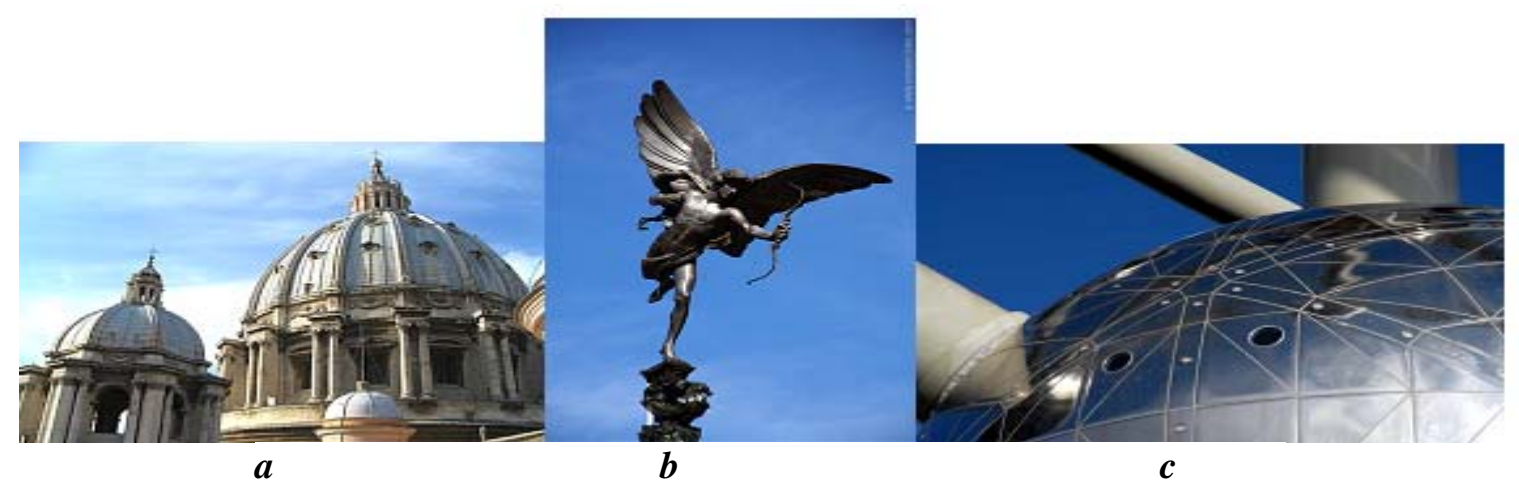

Figure 1. a-The Dome of the church of San Gioacchino in Rome [1], b-The winged Eros in London [2] and c-the Atomium in Brussels

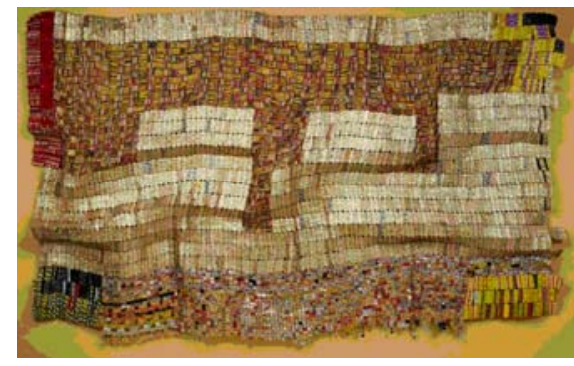

$\mathbf{a}$

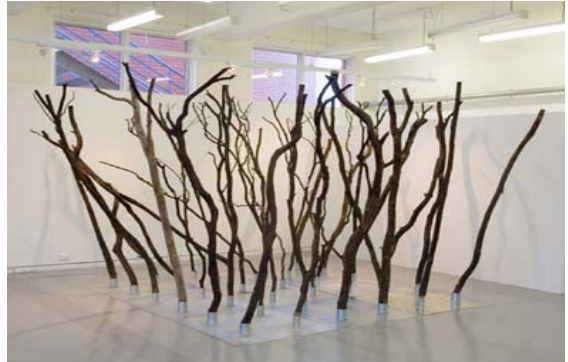

b

Figure 2. a-El Anatsui, Metropolitan Museum, metal tapestry, and b-Leanne Mooney, Toyota Community Spirit Gallery, Australia, copper and aluminum

Diagnostics of cultural heritage objects is usually made by divergent or parallel beams of laser light with uniform, energy density distribution, below the damage threshold. However, when metal artworks with complex surface geometry (with a pronounced local concave surface) are tested, the laser energy density can very much increase due to unwanted focusing of laser light over the damage threshold.

Having in mind the importance of metals in cultural heritage, a series of experiments were conducted in order to determine the maximum energy density, safe for testing and cleaning cultural heritage objects made of different metals. This paper presents the results of interaction of the ruby laser light and objects of copper and aluminum.

The results of laser light and materials were investigated by scanning electron microscopy.

\section{EXPERIMENTS}

The ruby laser used in the experiment operated in the TEM00 mode, Q-switched. The pulse length was $\mathrm{t}=30 \mathrm{~ns}$, the wavelength of the laser light $\lambda=694.3 \mathrm{~nm}$, and the coherent length $1 \mathrm{c}=1 \mathrm{~m}$. The output beam of light was $\Phi=16 \mathrm{~mm}$. The output energy was $\mathrm{E} 1 \mathrm{~J}$ with the Gaussian distribution, and the energy density $D_{E}=500 \cdot 10^{3} \mathrm{~J} / \mathrm{m}^{2}$.
The process of interaction was taking place in atmospheric conditions. Focal length of lens for focusing laser light was $\mathrm{f}=0.1 \mathrm{~m}$. The sample was placed normal in front of the laser beam. Changing of laser light energy density was made the changing the distance of the sample relative to the lens.

Metal objects exposed to the ruby laser radiation, are of unknown age, with flat shape with a thin layer of deposits. Fig. 3a shows the surface of copper objects with four zones of interaction, and in Fig. $3 \mathrm{~b}$ the surface of aluminum after interaction and application of a thin film of gold for microscopic examination.

Table 1 and Table 2 present the parameters of the laser beam and the zone of interaction for copper and aluminum samples, with comparable or very close laser light densities.

The effects of laser light irradiation are studied using a JEOL JSM-6610LV scanning electron microscope (SEM) connected to an INCA350 energy-dispersive EDX unit. To accelerate, an electron voltage of $20 \mathrm{kV}$ was chosen. The EDX unit performed the chemical analysis of the cleaning zone and the sediment composition; the area of the sediment covered the case.

The surface of the samples before ion analysis was coated with a thin gold layer, $20 \mathrm{~nm}$ thick and with $19,320 \mathrm{~kg} / \mathrm{m}^{3}$ density, in order to achieve better image structure. 


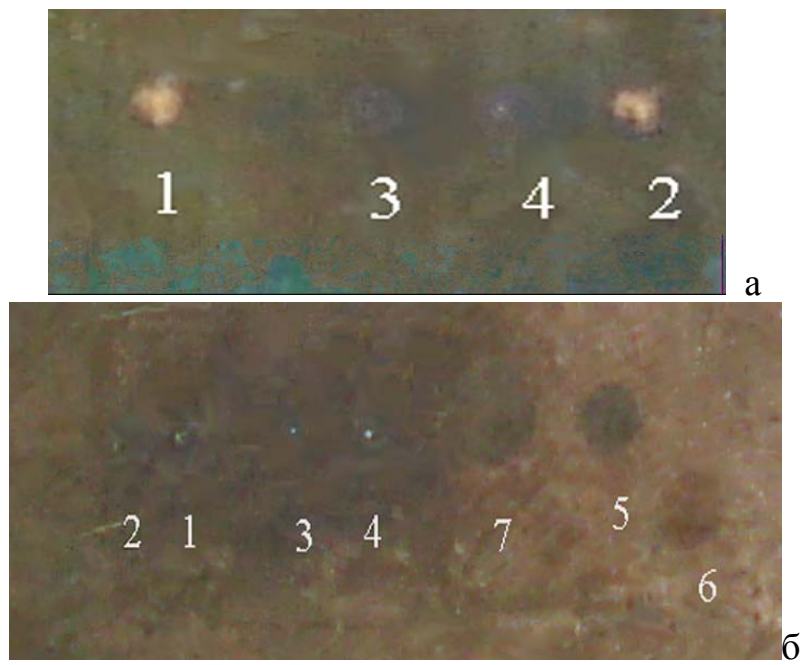

Figure 3. Interaction zones on a-copper and b-aluminum artwork.

Table 1. Experimental parameters of the laser and copper samples interaction

\begin{tabular}{|l|l|l|l|l|}
\hline copper & 1 & 2 & 3 & 4 \\
\hline$\Phi \cdot 10^{-3}[\mathrm{~m}]$ & 1,21 & 1,62 & 3,33 & 3,0 \\
\hline $\mathrm{S} \cdot 10^{-6}\left[\mathrm{~m}^{2}\right]$ & 1,13 & 2,06 & 8,76 & 7,06 \\
\hline $\mathrm{E}[\mathrm{J}]^{*}$ & 0,9 & 0,9 & 0.9 & 0.9 \\
\hline $\mathrm{D}_{\mathrm{E}}=\mathrm{E} / \mathrm{S}\left[\cdot 10^{3} \mathrm{~J} / \mathrm{m}^{2}\right]$ & 796 & 437 & 102,8 & 61,6 \\
\hline
\end{tabular}

Table 2. Experimental parameters of the laser and aluminum samples interaction

\begin{tabular}{|l|c|c|c|c|c|c|r|}
\hline Aluminum & 1 & 2 & 3 & 4 & 5 & 6 & 7 \\
\hline$\Phi \cdot 10^{-3}[\mathrm{~m}]$ & 1,4 & 1,72 & 1,0 & 1,1 & 2,5 & 3,3 & 3,9 \\
\hline $\mathrm{S} \cdot 10^{-6}\left[\mathrm{~m}^{2}\right]$ & 1,54 & 2,32 & 0,78 & 0,94 & 4,91 & 8,55 & 11,9 \\
\hline $\mathrm{E}[\mathrm{J}]^{*}$ & 0,9 & 0,9 & 0,9 & 0,9 & 0,9 & 0,9 & 0,9 \\
\hline $\begin{array}{l}\mathrm{D}_{\mathrm{E}}=\mathrm{E} / \mathrm{S} \cdot 10^{3} \\
{\left[\mathrm{~J} / \mathrm{m}^{2}\right]}\end{array}$ & 487 & 387 & 981 & 842 & 183 & 105 & 75,4 \\
\hline
\end{tabular}

\section{RESULTS AND DISCUSSION}

The interaction of laser beams with materials is a complex phenomenon that depends on many factors. Laser ablation is a process that consists of optical, photo thermal, photo acoustic and photo mechanical phenomena, which depends on the parameters of the laser beam and materials. The energy density of the laser beam, the time of irradiation or pulse length, the wavelength, and the energy distribution within the beam are the characteristics related to laser. The reflection and absorption coefficients, surface shape, homogeneity, temperature coefficient, melting point, and boiling point are parameters related to the material of the object.

Macroscopic, visual analysis of the tested samples of cultural heritage objects (Figs. 3a and 3b) show that the applied laser energy density caused more or less removal of deposits. Microscopic tests, conducted by SEM and EDX, made possible to determine the limit laser density energy that cleans the surface without degradation. Figures 4 and 5 present the obtain results.

Data for chemical composition of copper, weight $\%$ are given in Table 3 and for aluminum in Table 4. EDX analysis confirms the zone of complete cleaning (in the center of the zone of interaction) and the presence of sediment in the peripheral region.

These results indicate that only a part of the interaction zone (center) is without sediment and that in this zone, the percentage of copper is nearly $90 \%$, while in the zone with incomplete ablation the percentage of copper is under $70 \%$. The presence of carbon and oxygen was observed in the sediment.

SEM and EDX analysis confirmed that interaction zones No. 3 and No. 4 show incomplete cleaning of the surface of copper samples, but no melting effects. Results of chemical analysis of interaction zone No. 3, shown in Table 3, indicate that the energy density of $100 \cdot 10^{3} \mathrm{~J} / \mathrm{m}^{2}$ reduced carbon content $(7.29 \%)$ and oxygen $(4.78 \%)$ content compared to the sediment zone $(21.76 \% \mathrm{C}$ and $8.33 \% \mathrm{O})$. In this zone, partial removal of the organic sediment layer occurred. A similar phenomenon is present in interaction zone No. 4. The laser energy density was around $60 \cdot 10^{3} \mathrm{~J} / \mathrm{m}^{2}$, which is the allowed laser energy density for diagnostic methods for this object.

Aluminum is known as a material that has an extremely high coefficient of reflection of electromagnetic radiation in the visible spectrum for $\lambda=$ $694.3 \mathrm{~nm}, \mathrm{r}=80 \%$ [12]. The objects of aluminum, which reflect as mirror, are very unfit, both for diagnosis and for treatment by laser light. Zone no. 1 was exposed to the laser beam with power density of over $500 \cdot 10^{3} \mathrm{~J} / \mathrm{m}^{2}$. In this zone, melting of the material occurred.

In zones with labels 2 and 6, laser energy density is lower (about 400 and $100 \cdot 10^{3} \mathrm{~J} / \mathrm{m}^{2}$ ). However, in these areas too partial interaction occurs, with unwanted results. The central part of the zone is critical due to Gaussian distribution of energy within the beam. It means that the use of laser light with energy density below $100 \cdot 10^{3} \mathrm{~J} / \mathrm{m}^{2}$ is allowed (Table 3 ).

SEM and EDX analysis show that, although copper and aluminum have different optical and thermal coefficients, thresholds of damage for both artifacts have similar values. When lasers with frequency greater than $5 \mathrm{~Hz}$ are used, the threshold density is much lower.

According to data available in the literature, the threshold density significantly decreases when lasers with wavelengths in infrared or ultraviolet spectrum are used. For excimer lasers [17.18], with $f$ $=5 \mathrm{~Hz}$, the damage threshold for copper is lowered below $5 \cdot 10^{3} \mathrm{~J} / \mathrm{m}^{2}$. 
Table 3. Copper, chemical composition, mass \%

\begin{tabular}{|l|c|c|c|c|c|c|c|}
\hline Spectrum & $\mathbf{C}$ & $\mathbf{O}$ & $\mathbf{S}$ & $\mathbf{C l}$ & $\mathbf{C u}$ & $\mathbf{Z n}$ & Total \\
\hline $\begin{array}{l}\text { Laser2 } \\
\text { (center) }\end{array}$ & 6.72 & 2.90 & 0.00 & 0.00 & 89.36 & 1.02 & 100.00 \\
\hline $\begin{array}{l}\text { Laser2 } \\
\text { (deposit) }\end{array}$ & 27.42 & 8.54 & 0.13 & 0.30 & 62.52 & 1.08 & 100.00 \\
\hline $\begin{array}{l}\text { Laser3 } \\
\text { (center) }\end{array}$ & 7.29 & 4.78 & 0.00 & 0.00 & 87.93 & 0.00 & 100.00 \\
\hline $\begin{array}{l}\text { Laser3 } \\
\text { (deposit) }\end{array}$ & 21.76 & 8.33 & 0.00 & 0.29 & 69.62 & 0.00 & 100.00 \\
\hline
\end{tabular}


Figure 4. SEM zone and EDX spectrum of laser light and surface of copper samples interaction (1 to 4 from top to bottom)
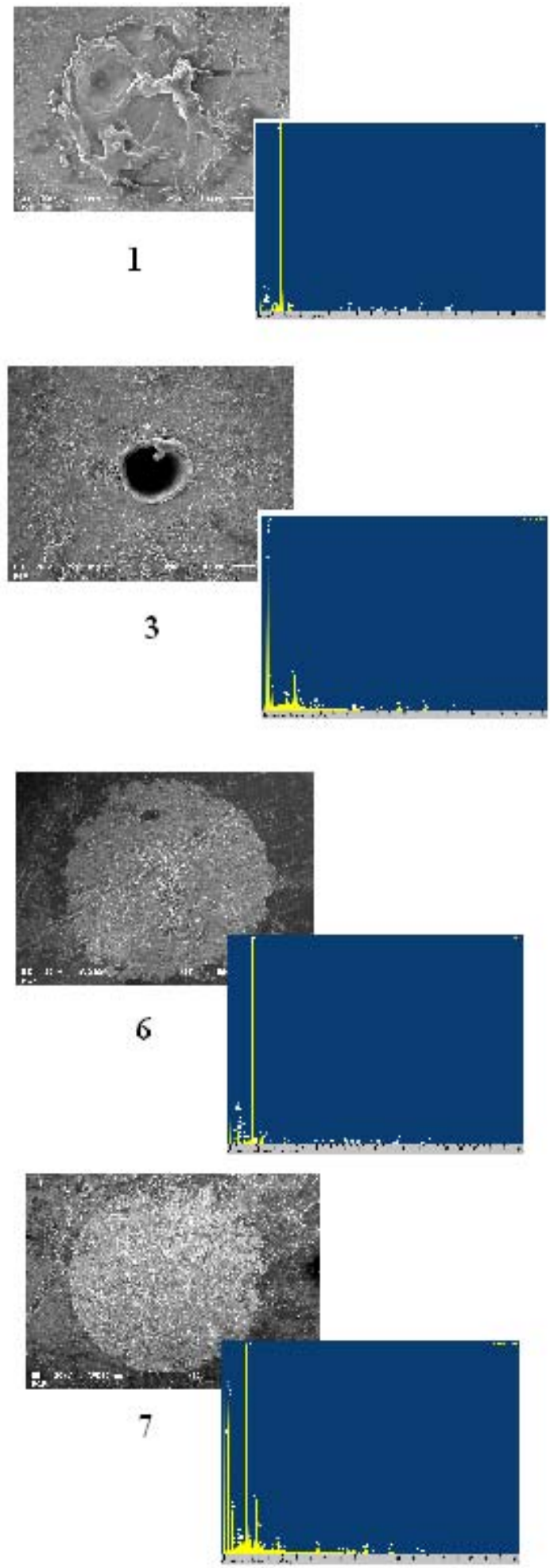

Figure 5. SEM zone and EDX spectrum of laser light and surface of aluminum samples interaction $(1,3,6$ an 7

$$
\text { zones) }
$$

\section{CONCLUSION}

This paper presents the results of the interaction effects of ruby laser light onto the surface of copper and aluminum objects. It is useful to determine the damage threshold for a chosen wavelength, alt- 
hough light in the visible part of the spectrum is commonly used in diagnostic methods.

EDX analysis determined the composition of metal objects and sediment deposits.

SEM and EDX analyses show that the maximum allowable energy density is $100 \cdot 10^{3} \mathrm{~J} / \mathrm{m}^{2}$ for ruby-laser light (Q-switch) in diagnostic methods and in the cleaning of sediment deposited on the surface of artwork without degradation of the surface and melting of copper and aluminum. Specified threshold energy density is related to diagnostic methods and methods for removing surface sediments without degradation of surface and melting of copper and aluminum.

The laser beam with energy density of $20 \cdot 10^{3} \mathrm{~J} / \mathrm{m}^{2}$ for both cases show the effects of partial removal of deposits. With this energy density it is necessary to repeatedly act on the same zone, in order to get satisfactory cleaning results.

\section{ACKNOWLEDGMENTS}

This work was financially supported by the Ministry of Science and Technological Development of Serbia under Project No. TR-19205A.

\section{REFERENCES}

[1] www.aviewoncities.com

[2] www.atomium.be

[3] www.metmuseum.org 32.pdf

[4] http://www.courts.alaska.gov/forms/pub-

[5] M. Bas, I. Stitch, Laser Handbook, vol.5, Nort Holland, Amsterdam 1985.

[6] Hybrid sculpture 2009, Toyota Community Spirit Gallery, Melbourne, Australia 2009, 45.

[7] S. Polić-Radovanović, Primena lasera $u$ obradi, zaštiti i dijagnosticiranju materijala predmete kulturne baštine, $\mathrm{PhD}$ thesis, Belgrade University 2007.

[8] S. Siano, Principles of Laser Cleaning in Conservation, Handbook on the Use of Lasers in Conservation and Conservation Science, COST G7 (2007).
[9] I. Cooper, Laser Cleaning in Conservation: An Introduction, Butterworth-Heinemann, Oxford, UK 1998.

[10] J. F. Asmus. Laser clean delicate art work, Laser Focus 1976:56, Asmus, J.: Serendipity, punctuated. Proceedings of LACONA VI, Vienna 2005, in print, Springer-Verlag, Heidelberg 2006.

[11] M. J. Weber, Handbook of lasers, Lawrence Berkeley National Laboratory, University of California, Berkeley, California, CRC Press LLC, 2001.

[12] W. Silfvast, Laser Fundamentals, Cambridge University Press, 2004.

[13] A. Milosavljević, M. Srećković, S. Ristić, Structural Changes of an Al-Li-Cu-Mg Alloy During Thermo-Mechanical and Laser Treatment Aluminum, International Journal for Industry Research and Application 3 (1997) 434-438.

[14] S. Ristić, M. Srećković, Z. Burzić, Laser Domages of Thread Generation of Construction Materials in Aeronautics, International Conference on Laser 97, NJ, Louisana, Proceedings (1997) 484-490.

[15] M. Srećković, A. Kovačević, S. Bojanić, Lj. Vulićević, S. Ristić, V. Rajković, Damages Induced by Laser beams in Organic Materials, Laser Physics, 11, 3 (2001) 336-342.

[16] A. Kovačević, M.Srecković, R. Gospavić, S.Ristić, P. Jovanić, Laser-PMMA interaction and mechanical stresses, Acta Physica Polonica 112, 5 (2007) 981-986.

[17] S. Polić-Radovanović, M. Srećković, Z. Nedić, A. Bugarinović, M. Timotijević, B. Timotijević, S. Ristić, The application of infrared spectroscopy in comparative investigation of possibilities of laser processing and protection of materials for icons, ICOSEC, Ohrid 2006.

[18] A. Zendehnam, M. Mirzaei and M. Khaneghaie, Study of reflection power and surface roughness of $\mathrm{Cu}$ nanolayers thin film with respect to various deposition rates of sputtering, Journal of Physics: Conference Series 61 (2007) 1326-1330.

[19] S. Ristic, S. Polic-Radovanovic, B. Katavic, M. Kutin, Z. Nikolić, M. Puharić, Rubi laser beam interaction with ceramic and cooper artifacts, Journal of Russien Laser Research, 31, 4 (2010) 401-412. 
$\operatorname{son}$

БАКАР И АЛУМИНИЈУМ У КУЛТУРНОЈ БАШТИНИ: АНАЛИЗА ПРАГА
ОШТЕЪЕЬА МАТЕРИЈАЛА У ИНТЕРАКЦИЈИ СА РУБИНСКИМ ЛАСЕРОМ

Сажетак: У савременој уметности и архитектури бакар и алуминијум су материјали који имају технолошку, функционалну и експресивну вредност. Због тога је у области културне баштине од великог значаја проучавање могућности заштите ових материјала недеструктивним методама. У раду су приказани резултати деловања ласерске свјетлости таласне дужине $\lambda=694.3$ нм (рубински ласер, Q - switch mod) на узорке прекривене депозитом. Циљ испитивања је био да се одреде максималне густине енергије ласерског снопа које склањају депозит, а не ступају у интеракцију са основним материјалом. Одабрани узорци од бакра и алуминијума су били дуги низ година изложени атмосферским утицајима. Ефекти деловања ласерске светлости су испитивани скенирајућим електронским микроскопом.

Кључне речи: ласер, интеракција, културна баштина. 